\title{
Applying The Concept Of Green Cities In Nigeria: Challenges And Prospects
}

\author{
Faith U. Ekong \\ Department of Urban and Regional Planning \\ Faculty of Environmental Studies \\ University of Uyo, Uyo. Akwa Ibom State, Nigeria
}

\begin{abstract}
One of the most pressing issues in Nigeria today is rapid urbanisation and its impacts. The environmental sustainability of cities in Less Developed Countries generally has been a key concern and the concept of "Green Cities" is being promoted as a response. Urban planners have been at the forefront in implementing the green city agenda in developed countries. In Nigeria, it remains essentially a concept. This concept is only discussed in seminar and conference papers but definitive action is lacking. There has been no policy response either at national or state levels to implement the green city agenda. This is inspite of the obvious climate change effects - excessive flooding and the environmental challenge manifested in failed refuse disposal systems in cities across the country, lack of open spaces, overcrowding and development of unplanned neighbourhoods. The paper will address these questions, is the green concept relevant to Nigeria; what are the challenges in implementing the green agenda in Nigeria, what policy programme responses are needed to apply the concept in Nigerian cities and what will be the specific role of planners?
\end{abstract}

Keywords: urbanisation, green city, sustainable environment, urban planning, policies.

\section{INTRODUCTION}

The rate of urbanisation especially in the developing world is on the increase due mainly to natural increase (migration and birth rates). The UN (2007) estimated that by 2050 over $70 \%$ of the people will live in cities especially in Asia and Africa. That report noted that globally, urban population has quadrupled since 1950s with the cities of the developing world accounting for over $90 \%$ of the world population. African urban centres for instance are growing in leaps and bounds, thus resulting in exploding cities (Oyesiku, 2009). This growth which is put at $5.50 \%$ is far above the general $3 \%$ rate for developing countries. West Africa also has its own share in this urban explosion. Though there are indications of overexaggeration (Potts, 2013) and differences in the general overview within the region (Africa polis/SEDET, 2012) yet urban growth remains one of the fastest in the world.

The state of Nigerian cities has been carefully documented over the years (Onibokun and Faniran 1992), Agbola and Agunbiade; 2009, Agbola et al 2011; Atebije et al, 2014). Generally, in Nigeria, the growth and complexity of human settlements and particularly the process of urbanisation have been phenomenal since it is increasing at a greater rate than the capacity and capability of urban managers, city dwellers especially migrants, retire to what planners and city managers call slum (Agbola et al, 2011). This has posed significant quality - of - life challenges such as rising inequality and crimes. Today, Nigeria has some of the world's most polluted cities and most steeply rising greenhouse gas emissions eg. Lagos, Aba, Port Harcourt, etc. 
Generally, Nigerian cities have the challenge of high population growth rates; inadequate housing and infrastructure; an economy dominated by the informal sector activities, rising crime rates and inadequate water supply, waste disposal, traffic and human congestion (Agbola and Agunbiade, 2009). At the moment, the population growth has been estimated at 4.48\% (World Bank, 2014).

The implications of the rapid urban growth have been described as varied with diverse consequences that are clearly seen in inadequate housing and infrastructure; an economy dominated by the informal sector activities, rising crime rates and inadequate water supply, waste disposal, traffic and human congestion. This paper, therefore, is an attempt to consider the concept of green cities and see how this feeds into the discussion on environmental sustainability in Nigeria and her efforts to achieve the Sustainable Development Goals. The paper also looked at the challenges and prospects of implementing the green cities model in Nigeria, assessed the role of the Urban and Regional Planners and outlined the requirements necessary to create sustainable green cities in the country.

\section{The Study Area}

Fig. 1 is the Nigeria Population Map. It plots the cities locations with color intensity as per the city population. It also gives an idea about the population. The Nigerian Population Map displays top ten populated cities of Nigeria. Below is the list of most populated cities in Nigeria. Table 1presents ranked cities with population of 20,000 and above. Though the list is not exhaustive we see can more than one hundred cities spread all over the country. The table shows that there is no state without two or more cities.

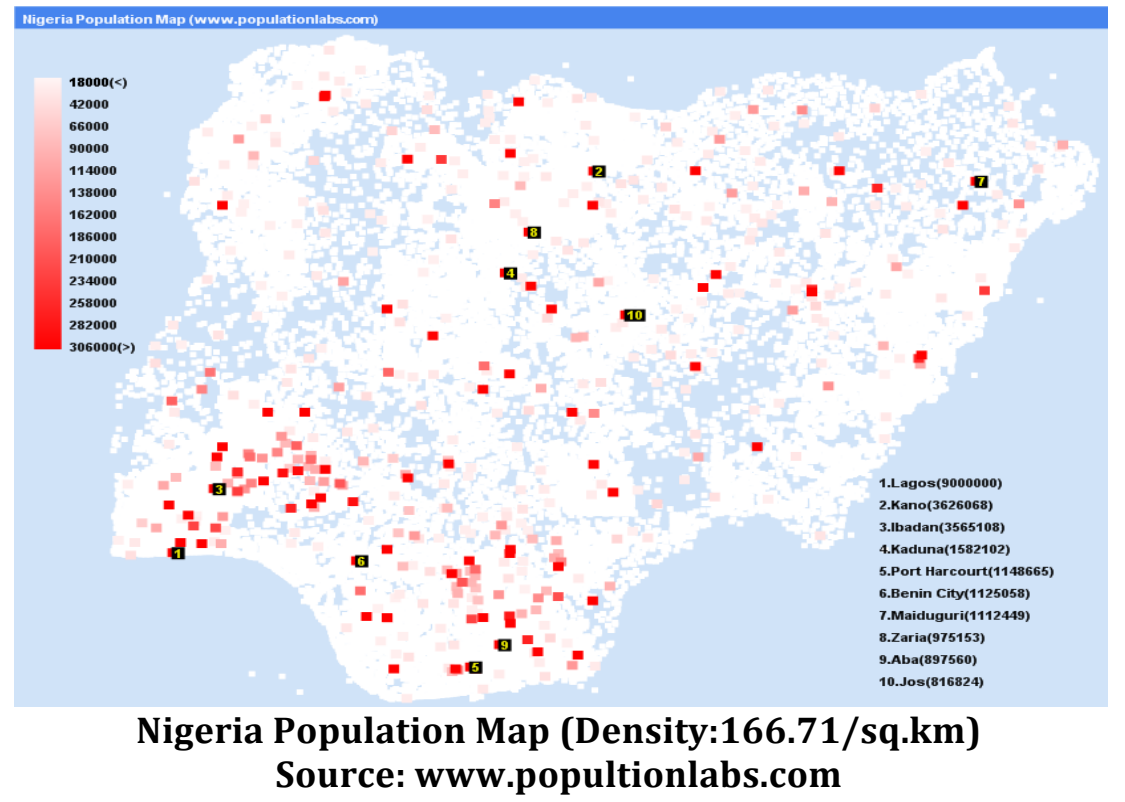

\section{Urbanisation in Nigeria}

\section{LITERATURE REVIEW}

Following the oil boom prosperity of the 1970s and the massive improvement in roads development and availability of vehicles, Nigeria since independence has become increasing urbanized and urban- oriented. Although, Nigeria does not have the highest proportion of urban population in sub-Saharan Africa, it has more large cities and the highest total urban population within the region. At the moment more than 100 cities in Nigeria each estimated to have more than 80,000 inhabitants as shown in Table 1.

The cities are well spread within the country as each of the 36 states has more two cities. Virtually all of these cities are growing at rates that may double their population before 2020 . 
This is based on the fact that many of these cities has growing manufacturing sectors (steel plants, car assembly, large construction companies, trading corporation, financial institutions); they contain large government offices and apartments with variety of small/informal businesses (LCC, 1991; populationlabs (2011); Onibokun and Faniran,1992). Also, vast majority of salaried jobs remain urban rather than rural based.

Table 1: Ranked Cities with population of 80,000 and above in Nigeria

\begin{tabular}{|c|c|c|c|c|c|c|c|c|}
\hline Rank & City & Population & Rank & City & Population & Rank & City & Population \\
\hline 1 & Lagos(Lagos) & 9000000 & 34 & Gombe(Gombe) & 250258 & 67 & Ilobu(Western State) & 118089 \\
\hline 2 & Kano(Kano) & 3626068 & 35 & Jimeta(Western State) & 248148 & 68 & Jalingo(Taraba) & 117757 \\
\hline 3 & Ibadan(Oyo) & 3565108 & 36 & Gusau(Zamfara) & 226857 & 69 & Okigwi(Imo) & 115499 \\
\hline 4 & Kaduna(Kaduna) & 1582102 & 37 & Mubi(Adamawa) & 225705 & 70 & Offa(Western State) & 113830 \\
\hline 5 & Port Harcourt(Rivers) & 1148665 & 38 & Ikire(Western State) & 222160 & 71 & Esuk Oron(Akwa Ibom) & 112033 \\
\hline 6 & Benin City(Edo) & 1125058 & 39 & Owerri(Imo) & 215038 & 72 & Nsukka(Enugu) & 111017 \\
\hline 7 & Maiduguri(Borno) & 1112449 & 40 & Shagamu(Ogun) & 214558 & 73 & Nguru(Yobe) & 111014 \\
\hline 8 & Zaria(Kaduna) & 975153 & 41 & Ijebu-Ode(Ogun) & 209175 & 74 & Hadejia(Jigawa) & 110753 \\
\hline 9 & Aba(Abia) & 897560 & 42 & Ugep(Cross River) & 200276 & 75 & Ijebu-Igbo(Ogun) & 109261 \\
\hline 10 & Jos(Plateau) & 816824 & 43 & Nnewi(Anambra) & 193987 & 76 & Uromi(Western State) & 108608 \\
\hline 11 & Ilorin(Kwara) & 814192 & 44 & Ise-Ekiti(Ekiti) & 190063 & 77 & Birnin Kebbi(Kebbi) & 108164 \\
\hline 12 & Oyo(Western State) & 736072 & 45 & Ila Orangun(Western & 1791 & 78 & Pindiga(Gombe) & 106322 \\
\hline 13 & Enugu(Enugu) & 688862 & 45 & State) & $1 / 91$ & 79 & Azare(Bauchi) & 105687 \\
\hline 14 & Abeokuta(Ogun) & 593100 & 46 & Saki(Oyo) & 178677 & 80 & Nkpor(Anambra) & 103733 \\
\hline 15 & Abuja(Abuja Federal & 590400 & 47 & Bida(Western State) & 171656 & 81 & Ikerre(Ekiti) & 103054 \\
\hline 15 & Capital Territory) & 590400 & 48 & Awka(Anambra) & 167738 & 82 & Lafiagi(Western State) & 102779 \\
\hline 16 & Sokoto(Sokoto) & 563861 & 49 & Ijero-Ekiti(Ekiti) & 167632 & 83 & Kontagora(Niger) & 98754 \\
\hline 17 & Onitsha(Anambra) & 561066 & 50 & Inisa(Western State) & 164161 & 84 & Yola(Adamawa) & 96006 \\
\hline 18 & Warri(Delta) & 536023 & 51 & Abuja(Western State) & 162135 & 85 & Biu(Borno) & 95005 \\
\hline 19 & Calabar(Cross River) & 461796 & 52 & Sapele(Delta) & 161686 & 86 & Olupona(Western State) & 95002 \\
\hline 20 & Katsina(Katsina) & 432149 & 53 & Kishi(Western State) & 155510 & 87 & Lere(Kaduna) & 93290 \\
\hline 21 & Akure(Ondo) & 420594 & 54 & Gbongan(Western State) & 139485 & 88 & Wukari(Western State) & 92933 \\
\hline 22 & Bauchi(Bauchi) & 316149 & 55 & Ejigbo(Western State) & 138357 & 89 & Igbo Ora(Western State) & 92719 \\
\hline 23 & Ebute Ikorodu(Lagos) & 313439 & 56 & Funtua(Katsina) & 136811 & 90 & Emure-Ekiti(Ekiti) & 90645 \\
\hline 24 & Makurdi(Benue) & 292645 & 57 & Igboho(Western State) & 136764 & 91 & Isieke(Ebonyi) & 89990 \\
\hline 25 & Minna(Niger) & 291905 & 58 & Buguma(Rivers) & 135404 & 92 & Ifo(Ogun) & 88272 \\
\hline 26 & Effon Alaiye(Western & 279319 & 59 & Ikirun(Western State) & 134240 & 93 & Igede-Ekiti(Ekiti) & 87282 \\
\hline & State) & & 60 & Abakaliki(Ebonyi) & 134102 & 94 & Effium(Ebonyi) & 86945 \\
\hline 27 & Ilesa(Osun) & 277904 & 61 & Okrika(Rivers) & 133271 & 95 & Idanre(Ondo) & 86468 \\
\hline 28 & Owo(Ondo) & 276574 & 62 & Amaigbo(Abia) & 127300 & 96 & Potiskum(Yobe) & 86002 \\
\hline 29 & Umuahia(Abia) & 264662 & 63 & Lafia(Nassarawa) & 127236 & 97 & Keffi(Nassarawa) & 85911 \\
\hline 30 & Ondo(Western State) & 257005 & 64 & Gashua(Yobe) & 125817 & 98 & Epe(Lagos) & 84711 \\
\hline 31 & Damaturu(Yobe) & 255895 & 65 & Modakeke(Western & 119529 & 99 & Gambaru(Borno) & 84672 \\
\hline $\begin{array}{l}32 \\
33\end{array}$ & $\begin{array}{l}\text { Ikot-Ekpene(Akwa Ibom) } \\
\text { Iwo(Western State) }\end{array}$ & $\begin{array}{l}254806 \\
250443\end{array}$ & 66 & $\begin{array}{l}\text { State) } \\
\text { Bama(Borno) }\end{array}$ & 118121 & 100 & Ogaminan(Kogi) & 84373 \\
\hline
\end{tabular}

Source: www.populationlabs.com

The problems and challenges posed by the rapid urban growth in Nigeria are immense. More easily observable and perhaps very frightening are the general human and environmental pollution, declining quality of life and underutilized as well as untapped wealth of human resources (Onibokun and Faniran, 1991). Housing and associated facilities (water, electricity, waste disposal) are grossly inadequate. Millions live in substandard environment called slums by planners, plagued by squalor and grossly inadequate social amenities (schools, health facilities and lack of open spaces for recreation). This brings the issue of liveability in these cities to fore. 
Liveability is the sum of the aspects that add up to the quality of life of a place including its economy, amenity, environmental sustainability, health and well-being, equity, education and learning and leadership (Plc, 2012). By every criterion, cities in Nigeria have low liveability indices as observed by many researchers (Oyesiku, 2009; Olupohunda, 2016; EIC; 2015, EIU, 2016) and bring to mind the green cities concept.

\section{Green Cities Concept}

Green cities are those cities that are environmentally friendly (Rode \& Burdett, 2015). The greening of cities requires some, or preferably such issues as controlling diseases and their health burden; reducing chemical and physical hazards; developing high quality urban environments for all; minimising transfers of environmental costs to areas outside the city and ensuring progress towards sustainable consumption. This can be achieved in terms of interlinked benefits of green city. Economically, the benefits include: agglomeration economies, lower infrastructure costs, reduced congestion cost while reducing carbon emissions and other environmental pressures. In terms of social benefits there will increase employment creation, poverty reduction and improved equity and quality of life including improved safety and community cohesion while Environmental benefits embedded in economic and social in such issues like reduced poverty which help improved public health and potential for improving ecosystems within urban areas.

From the foregoing, 'Green cities' combine greater productivity and innovative capacity with lower costs and reduced environmental impact. Relatively high densities are a central feature of green cities, bringing efficiency, gains and technological innovation through the proximity of economic activities while reducing resource and energy consumption. Urban infrastructure including streets, railways, water, and sewage systems come at considerably lower cost per unit as urban density rises.

Measures to green cities can increase social equity and quality of life. Enhancing public transport systems, for example, can reduce inequality by improving access to public services and other amenities, and by helping to relieve vehicle congestion in poorer neighbourhoods. Cleaner fuel for transport and power generation can reduce both local pollution and health inequality. Reducing traffic and improving conditions for pedestrians and cyclists can help foster community cohesion, an important aspect of quality of life. Children who live close to green spaces are more resistant to stress; have lower incidence of behavioural disorders, anxiety, and depression; and have a higher measure of self-worth. Green space also stimulates social interaction between children. It creates jobs on a number of ways: urban and peri-urban green agriculture, public transport, waste management and recycling. Green manufacturing clusters will develop drawing on knowledge from university and research laboratories. For example, about 100 largest metropolitan regions in U.S.A have far greater shares of low-carbon employment in wind and solar energy (80\%) and green buildings (85\%) in cities (Bookings and Battelle, 2011). 
Table 2: Average value US $\$ /$ ha $/ y$ of services provided by green space in urban are

\begin{tabular}{|l|l|l|}
\hline Service & Average (US $\$ /$ ha/yr) & Range \\
\hline Air quality regulation & $602(\mathrm{n}=9)$ & $56-1958$ \\
\hline Carbon sequestration & $367(\mathrm{n}=5)$ & $54-653$ \\
\hline Carbon storage & $2906(\mathrm{n}=3)$ & $1783-4815$ \\
\hline Storm water reduction & $857(\mathrm{n}=6)$ & $572-2362$ \\
\hline Energy savings & $1313(\mathrm{n}=34)$ & $321-1774$ \\
\hline Recreation \& amenity & $5882(\mathrm{n}=2)$ & $1984-9780$ \\
\hline Health effects & $17548(\mathrm{n}=1)$ & N/A \\
\hline
\end{tabular}

Source: Elmqvist, Setala, deGroot and Handel (2014)

Open space apart from recreational purpose its provides other services (air quality, carbon sequestration, carbon storage, storm water reduction, recreation \& amenity) as reflected in Table 2.

\section{From the foregoing, is the green concept relevant to Nigerian cities?}

The answer is yes especially when we consider the current scenarios in our cities. Nigeria's economy will continue to suffer especially as the advanced countries continue to implement the "Green Agenda" in energy use (buildings, urban transportation, urban LIU).
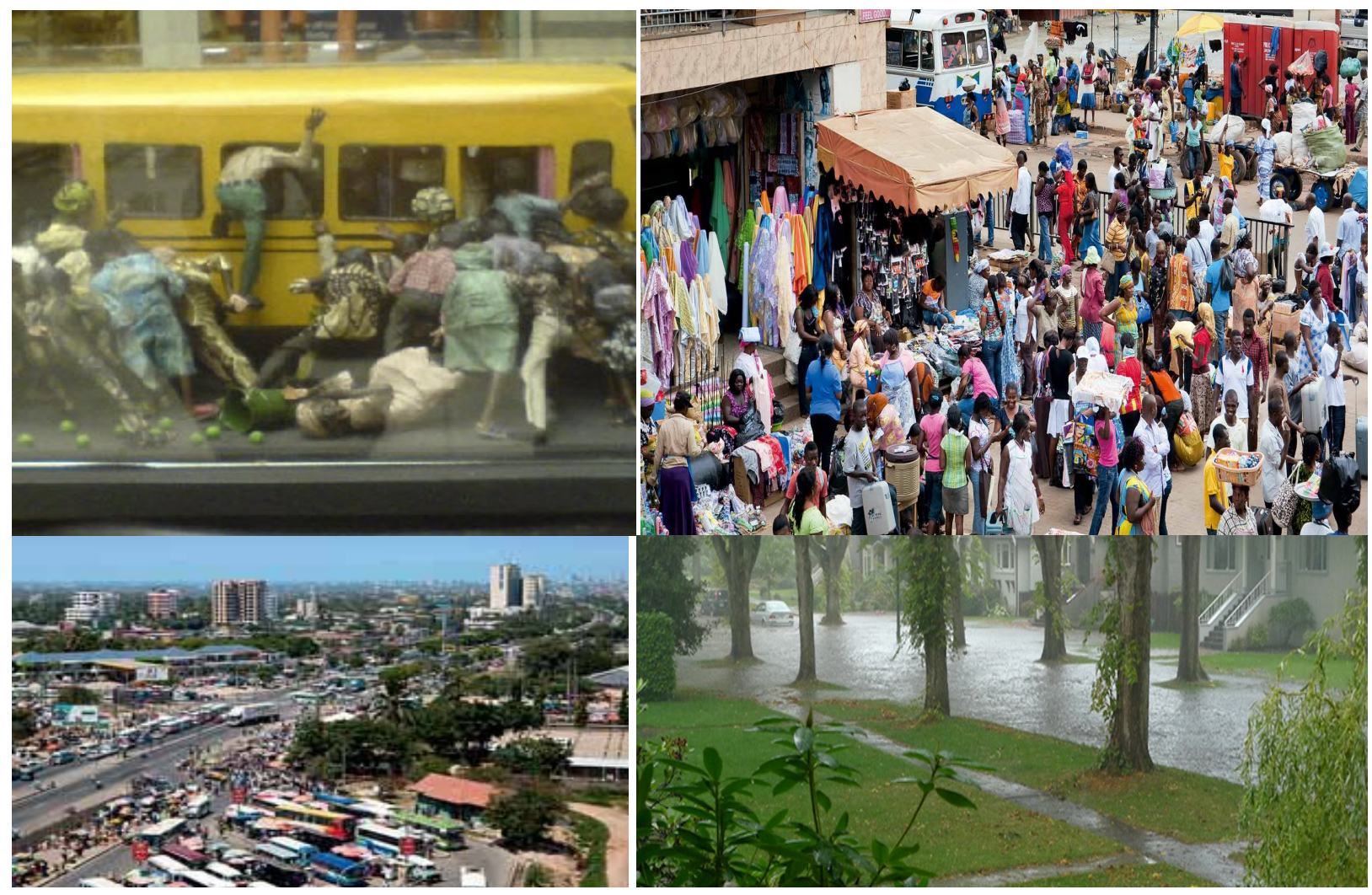

Lagos, for instance, was assessed as the third worst city on earth to live essentially because of congestion, and inadequate services (e.g. water supply and waste disposal). This was the key finding of the 2016 Global Liveability Index published by the Economist Intelligence Unit (EIU). The Lagos experience is one that is replicated across most other Nigerian cities. The concept of 
liveability assesses which locations around the world provide the best and worst living conditions. The assessment is based on the rating of relative comfort for over 30 qualitative and quantitative factors across 5 abroad categories i.e- stability in the system (city) health care, culture \& environment; education and infrastructure. Each factor in a city is rated as acceptable, tolerable, uncomfortable, undesirable or intolerable. For qualitative indicators, the rating is awarded based on the judgment of in-house analysts and in-city contributors: (EIU, 2015).

\section{What are the components of environmental sustainability?}

Environmental sustainability is seen as the maintenance of the factors and practices that contribute to the quality of environment on a long-term basis. It is the rates of renewable resource harvest, pollution creation and non-renewable resource depletion that can be continued indefinitely. Anything outside this will mean environmental degradation (Daly, 1990).

Environmental sustainability is not only about making decisions that will reduce negative impact on the environment i.e. reducing the amount of waste produced or using less energy but is concerned with the process that will lead to sustainable future environment i.e. sustainable environment. It involves making decisions and taking actions that are in the interests of protecting the natural world, with particular emphasis on preserving the capability of the environment to support human life (Toolkit, 2014).

\section{Sustainable City}

A sustainable city is a city designed with consideration of environmental impact, inhabited by people dedicated to minimization of required inputs of energy, water and food and waste output of heat, air pollution $-\mathrm{CO}_{2}$ and water pollution. It is related to two concepts: the concept of needs and the concept of limit.

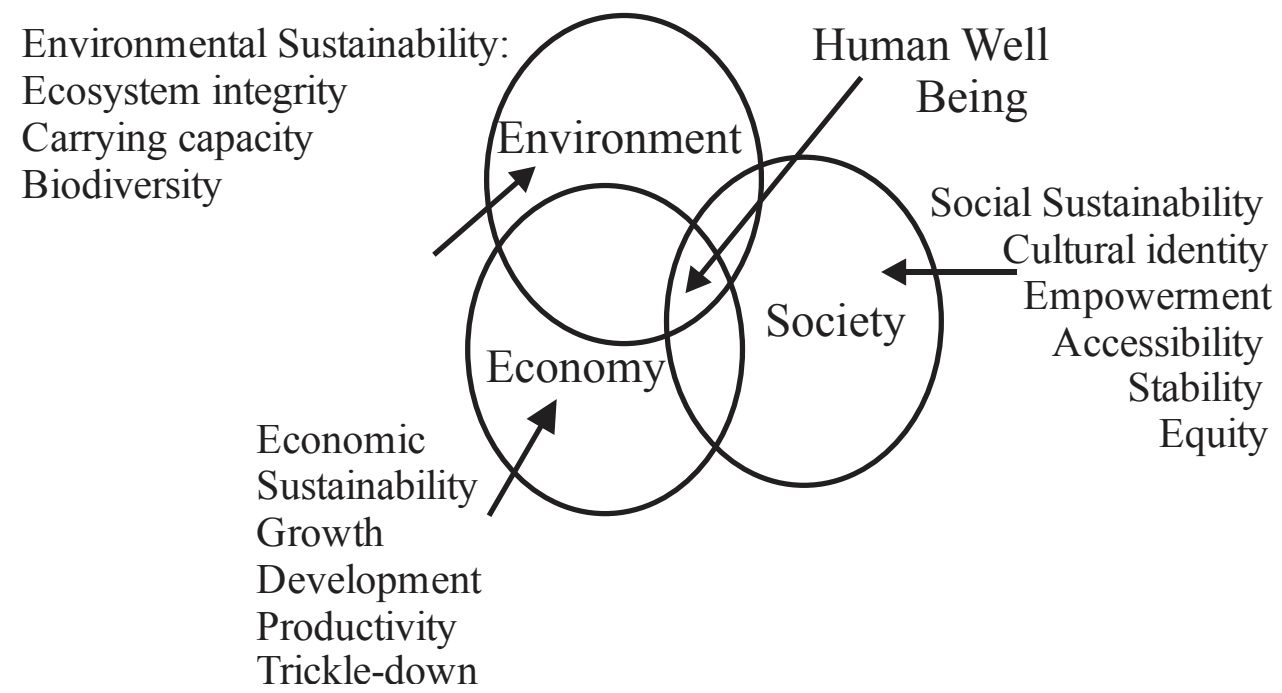

\section{Urban and Regional Planning}

One issue that has contributed to the failure to accept planning in most developing countries is the lack of universal adopted definition. Keeble (1976) defines planning as the art and science of ordering the use of land and character and siting of buildings and communication routes so as to secure the maximum practicable degree of economy, convenience and beauty. From this planning is an art of shaping and creating buildings and environment to meet various needs such as social, cultural, economic, and recreational and to provide healthy conditions for both 
rich and poor to live, work, move and recreate. The ultimate aim is to bring about the social and economic well-being of the citizenry and natural environment. Planning has also been defined as the art and science of ordering and managing land uses and the environment based on detailed understanding and analysis of social needs within the socio-economic and environmental health management and compatibility framework (NITP, 2014). It concerned itself with information, design, implementation and monitoring of land use plans and policies at all levels of human habitation- cities, regions and local. Onawu and Imasuen (2004) assert that planning is concerned with research and analysis, strategic thinking, architecture, urban design, public consultation, policy recommendation, implementation and management.

Physical planning is concerned with the spatial arrangement of urban and rural land uses for the purpose of creating orderly, economical, functionally, efficient and aesthetically pleasing environments for living, working, recreation and circulation. It is concerned at the local level (cities, towns, communities, etc) with the spatial arrangement of buildings and structures, roads, public utilities, community facilities and services and recreation areas to achieve order as well as economic, functional and aesthetic efficiency. It also involves conservation of natural resources and provision of socio-physical infrastructure to raise the living standards of people (citizens).

The goals of physical planning is lucidly captured in some sections of the Sustainable Development Goals particularly goals 11,12,13,14, 15 and 16

\section{Goal 11}

Make cities and human settlements inclusive, safe, resilient and sustainable

\section{Goal 12}

Ensure sustainable consumption and production patterns

\section{Goal 13}

Take urgent action to combat climate change and its impacts.

\section{Goal 14}

Conserve and sustainably use the oceans, seas and marine resources for sustainable development.

\section{Goal 15}

Protect, restore and promote sustainable use of terrestrial ecosystems, sustainably mange forests, combat desertification, and halt and reverse land degradation and halt biodiversity loss.

\section{Goal 16}

Promote peaceful and inclusive societies for sustainable development, provide access to justice for all and build effective, accountable and inclusive institutions at all levels.

To achieve these goals in Nigeria, town planners must be up to the task as encapsulated in the various definitions of planning presented here.

\section{Urban planning policies.}

All urban settlements in Nigeria i.e. settlement with population of 20,000 and above must have a Land Use plan to guide their physical development plan before definition. 


\section{Efforts towards urban renewal}

in older cities should provide public spaces, upgrade infrastructure, improve housing quality and preserve indigenous architecture.

\section{Create a stakeholder forum}

in every urban centre as part of urban governance.

\section{Rapid Pace of Urbanisation}

\section{CHALLENGES}

As depicted in Fig. 1 the rapid pace of urbanisation may tend to overwhelm cities where the struggle to develop infrastructure, mobilise and manage resources have negative consequences for the environment. Also the unpredicted nature of migration with lack of adequate data may pose a lot of drawbacks for the implementation of green city model.

Nigerians are open to buy ideas from World Banks, United Nations and other International Agencies, but are unable to actualise these concepts in our day to day activities as urban planners. Example, the NITP organised a workshop on good governance; ideas generated were ignored and treated as passing facts. Thus, the problem remains leaving us with local planning authorities that cannot function, state governments that do not have functioning and appropriate frameworks. No planning law in many states, no master plans; while the existing ones are very old or totally outdated and cannot be used.

\section{Lack of city wide data and information.}

The fundamentals for planning do not even exist; for instance, can any city in Nigeria tell us the number of housing units and the state of those houses? Can any Director of Planning or APA tell us they have records of all the streets and that houses on those streets are properly numbered? When dealing with situations like these planning becomes impossible because effective planning depends on adequate data. That is why it is easy for many inadequacies in urban planning to occur and crimes go on unabated. When we talk about inadequacy of urban services (live) the fundamental thing is about urban planning. Therefore it is the role of the NITP to make these issues clear to government at all levels, national, state and local. Until we get the land use planning right at the community level (neighbourhood) we will never get it right at the local or national level. NITP must interface with city administration and make the impact known from the primary school where the children are enlightened about the meaning of a city. It is only then that the "death cocktail" (ignorance, poverty, superstition, mistrust, etc.) will be removed from our society. The NITP and other professionals in the built environment must think through their roles.

\section{The social implications of traditional urban development}

The pattern of urbanisation in Nigeria raises important social challenges. Many urbanized areas are characterised by uncontrolled horizontal expansion leading to urban sprawl of affluent populations with lower development densities. This increased dependency on private car and peripheralisation of the urban poor, decreasing their access to the city and its workplace, services and infrastructure. They result in emergence of socially divisive neighbourhoods and significant increase in the level of informal development and business (slum) with no access to basic services, infrastructure and sanitation. 


\section{Urbanisation and environment}

Urbanisation goes hand in hand with increasing resource consumption, more energy, intensive food supply, and ever increasing flows of good and people. The scale of this problem in Nigeria is a serious one when consider the amount of housing required yearly to accommodate the teeming urban population, built million kilometers of roads and the other urban infrastructure. The nature of these investments will have significant effects on the potential of Nigeria to be green.

\section{Policy/legal Instruments available}

Numerous instruments for enabling green cities are available and tested but need to be applied in a tailored, context-specific way. In contexts with strong local government it is possible to envisage a range of planning, regulatory, information and financing instruments to advance green infrastructure investments, green economic development and a multitrack approach to greater urban sustainability. However, in the absence of this, it may be more prudent to adopt a more pragmatic and minimalist approach which primarily commits municipal sectors such as water, waste, energy and transport to a limited number of overarching strategic goals.

The green city concept also specifically suggests policy instrument to apply. Policy here refers to any form of intervention or societal response. It may include not only statements of intent, example, water policy, but also other forms of intervention, such as the use of economic instruments, subsidies, institutional reform, legal reform, decentralisation and institutional development. From here policy may be seen as a tool for the exercise of governance.

\section{Prospects of implementing Green Cities models in Nigeria}

Technological potential: cities are incubators of innovation due to the close interaction of their residents and workers who benefits from the exchange of ideas and opportunities. Here the various Universities, institutions and research laboratories, firms, skilled and service providers can pilot new technologies in the current high network environment. Trained professionals like planners will be on hand.

\section{Structural Capacity}

The environmental performance of cities is dependent on a combination effective green strategies and physical structure - urban form, size, density and configuration (LSE Cities, 2011). From the outline and our knowledge of Nigeria (Table 1) this will not pose any problems at all. The only thing that is needed is to these cities more compact, reduce travel distances and invest in green transport mode for energy efficiency. There is a growing evidence that compact urban environments with higher-density residential and commercial buildings (as opposed to low-density, sprawl like development) and a well distributed pattern of uses and an efficient, transport system (public transport, walking and cycling) reduces the energy footprint (Burgess, 2000, Bertrand 2004, Hoornweg et al, 2004 in LSE Cities 2011).

\section{Urban synergy and integration potential}

Recognising the interrelationship of energy systems and city fabric can lead to particular synergies as pioneered by the Rotterdam Energy Approach and planning water-sensitive urban design which helps to retain storm water in public spaces and parks, will increased reliability $\mathrm{f}$ urban water sustainability for urban agriculture (Ekong 2014) e.g. is the Unity Park Fig.2 along Udo Udoma Avenue in Uyo, Akwa Ibom State. Another example is the synergy of industrial sectors and resource flows output of one sector becomes the input of another to create circular economy (McDonough and Braungart, 2002). 
These prospects should encourage efforts of government and urban planners and managers to design cross-sectoral green city strategies in the numerous cities as is obtained in other countries e.g. the car-free neighbourhood in Vauban (London) Songo Eco-city (China).

\section{The Role Of Town Planners}

The role of town planners is captured in the Sustainable Development Goals listed in addition to the following:

- Revisit development control processes in all our cities. At the moment planning in Nigeria only focuses mainly on development control without basic data.

- Creating public awareness through education and creative ways of interplaying with urban communities. Public participation has never really been a strong part in Nigeria except on seminar/conference papers by planners who have to find a way to do it and doing it effectively. The obvious chaos that one experiences in the average Nigerian city need not be so. Examples of good planning during the colonial era existed in Port Harcourt, Calabar, Enugu, Jos and the other part of these cities remains till today as well-laid out neighbourhoods. The planning was done during the era of the development schemes.

- Train and retrain town planners. This mandatory training and retraining programmes should endeavour to expose them to best practices from all over the world. This is the intention of MCPDP and recently the MCPPEP organized by TOPREC are all geared towards training and retraining of all professional in the built environment especially town Planners.

- In the phase of dwindling resources we must deal with unbridled urban growth. In Indonesia for instance, planning is such that a young adult does not have to leave home until he has attained 18 years because everything he needs is within reach in the immediate environment. So this whole scale movement of unskilled and unschooled persons into the urban areas needs to be reviewed.

The fight for sustainable cities is actually the fight for overall development of the country we are too laid back. The dignity of a Nigerian like any citizen is identified by the quality of the environment in which he/she lives. Recently the European representative in Abuja stated that the size of the GDP is not always related to the quality of life in reaction to the observation by the IMF that the Nigerian economic life is high. We can observe from liveability index of the world's cities that this is true. The green cities concept is not an entirely new idea but to implement it in Nigeria will require putting Land Use Planning in its proper place in governance of the country. Everything about infrastructure planning, land use planning and management, housing are part of the green agenda for cities. In cities in advanced countries, the emphasis is on alternative energy sources, with importance on public transportation that is capable of moving large numbers of people across the cities at once without the pollution that comes from private automobile use; densification of urban development rather than sprawl improvement in open spaces.

These measures may look draconian but somehow we must control it. E.g. every landlord must know who his tenants are and what they do for a living (basic information), the national urban and regional planning commission needs to be set up. Even the federal government can consider constituting the commission. Every state as required must have its urban and regional planning board. It is important to have a definitive structure for implementing the green city agenda. Part of their responsibility is to create an action plan. This action plan is a strategy for maintaining urban plan sustainability. Our vision is to create opportunities today: 
- while building a strong bullet local economy

- vibrant and inclusive neighbourhoods

In conclusion, to create a sustainable urban environment, it is crucial to measure and assess policies, infrastructure, socio-economic factors, measure use, emissions and any other process that contribute to and profit from the city's metabolism, prosperity and quality of life. This will allow planning authorities, urban managers, and government in general to identify areas of opportunities as well as concern, and to respond by developing realistic sustainable goals. According to Kennedy et al (2007), sustainable city can only be one for which the inflow of material and energy resources, and disposal of wastes, do not exceed the capacity of the city's surrounding environment. In other words, in achieving environmental sustainability urban consumption must match or be below what the natural environment (forest, ocean, soil, etc) can provide and the resulting pollutants must not overwhelm the environment's ability to provide resources to human and other members of the ecosystem.

Also, since cities of different wealth levels impact the environment differently, plan to introduce green cities must recognise these facts. A uniform plan for all cities should not be developed rather, city specific plans should be advocated to depict culture, available resources and the environmental issues of individual city.

\section{References}

APA (2012). Policy Guide on Smart Growth, APA USA.

Atebije, N. (2014). Building Clean Cities in Nigeria: An Experience of Developing the New Federal Capital City, Abuja, Nigeria.

Agbola, T. and Agunbiade, E. M. (2009). Urbanization, Slum Development and Security of

Tenure: The Challenges of Meeting MDG 7 in Metropolitan Lagos, Nigeria.In: de Shebiniin, A. A Rahman, A.Barbieri, J. C. Fotso and Y. Zhu (eds) Urban Population-Environmental Dynamics in Developing World: Case Studies and Lessons Learned, Committee for International Co-operation in National Research in Demography(LICRED, Paris).

Bertaud, A. (2004) The Spatial Organisation of Cities: Deliberate outcome or unforeseen consequences? Working paper 2004-2010, Institution of Urban and Regional Development, University of California, Berkeley.

Burgress, R. (2000) The Compact city debate: A global perspective. In: Jenk, M. and Burgress R. (ed) compact cities: Sustainable urban forms for Developing Countries. Spon Press, London.

Daly, H. E. (1990) Toward some operational principles of Sustainable Development, Ecological Economic vol.2 pp1-6

Economist Intelligence Unit (2015) A summary of liveability Ranking and overview (online)

Faith Ekong (2014) overview of Global Warming, Environmental Sustainability and their implications for Construction Activities: Lead Paper Presented at the Nigerian Institute of Quantity Surveyors National Workshop holding at Uyo, AKS, $9^{\text {th }}-10^{\text {th }}$ October, 2014. Available@thenationonline.net/news/global-warming-affects-builtenivronment, December 2014

Jenks, M. (2000). Introduction: Sustainable Urban Form in Developing Countries In: Jenks, M \& Burgess, R.(eds) Compact Cities: Sustainable Urban Form for developing Countries. London \& New York: SPON Press, Taylor \& Francis Group.

Kennedy, C., Cuddihy, J. and Engel-yan, J. (2007) the changing metabolism of cities (online). Journal of Industrial Ecology, vol.11(2) pp43-59

London School Economics and Political Science (2011) toward the green economy., United Nations Environment programme.

McDonough, W. and Braugart, M. (2002) Craddle to Craddle: remaking the way we make things, North point press, New York. 
Onibukun, A. and Faniran, A. (1992) Urban Research in Nigeria, Institut francias de recherché en Afrique, IFRANigeria

Olupohunda, B. (2016) Lagos and the Liveable Cities Index, Nigerian Punch newspaper, August 30, 2016

Plc (2012) Liveable City Project; Centre for Sub-Tropical Design

Potts, D. (2013). Challenging the Myths of Urban Dynamics in Sub-Saharan Africa. The

Evidence from Nigerian Environment, Politics and Development Working Paper Series, Paper No.39. Department of Geography King's College, London.

Population Labs (2011) Population map of Nigeria available online@www.populationlabs.com

Satterthwaite, D. (19970. Sustainable Cities orCities that contribute to Sustainable Development?

Urban Studiec 34(10), pp.1667-1691.

Toolkit (2014) Environmental Sustainability accessed online at www.toolkit.smallbiz. nsw.gov.

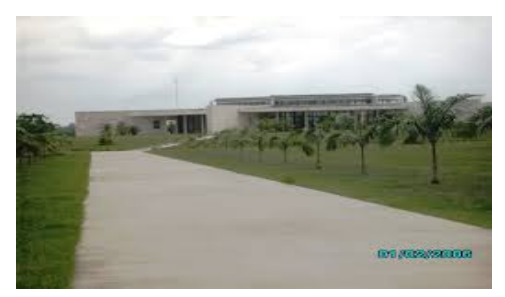

Fig.2 Unity Park in Uyo. 